Alaska Division of Geological \& Geophysical Surveys

MISCELLANEOUS PUBLICATION 155

\title{
DIGITAL ELEVATION MODELS OF SKAGWAY AND HAINES, ALASKA: PROCEDURES, DATA SOURCES, AND QUALITY ASSESSMENT
}

by

A.E. Macpherson, D.J. Nicolsky, and E.N. Suleimani

Alaska Earthquake Center, University of Alaska Fairbanks

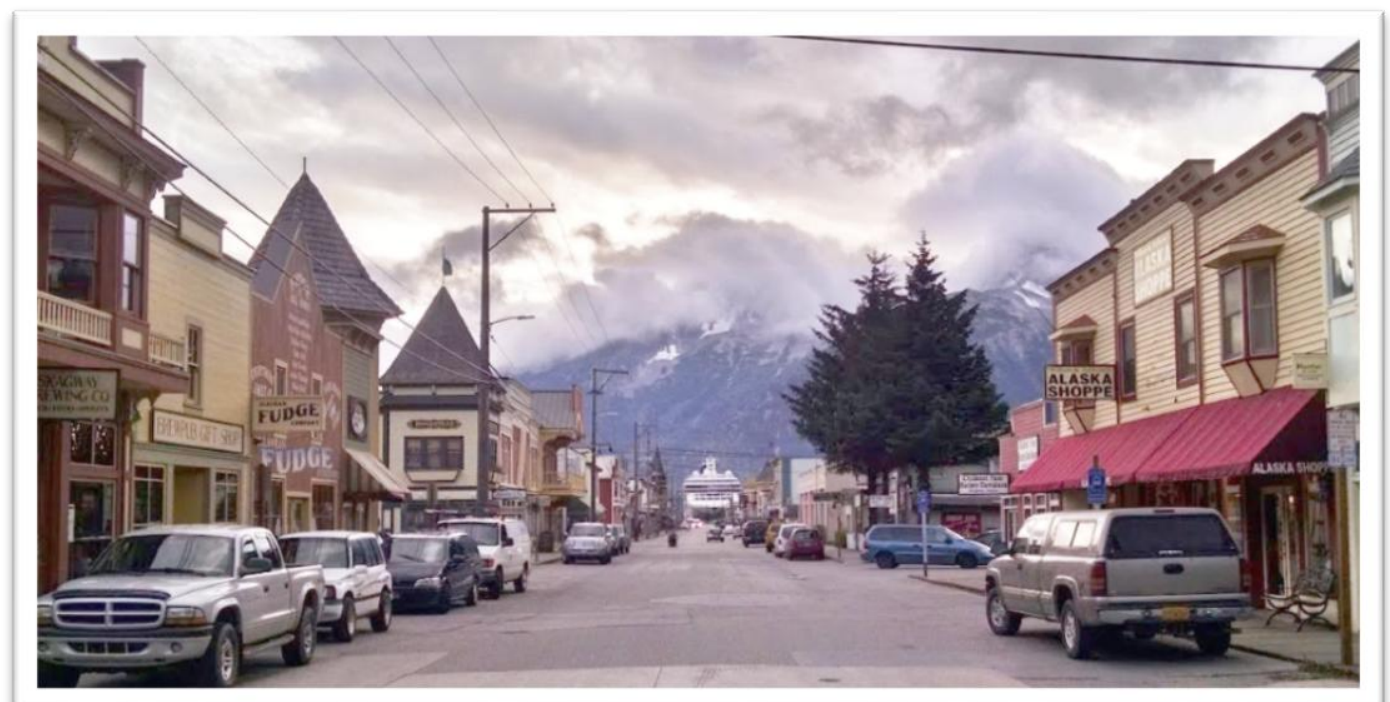

Cruise ship in port, Broadway Street, downtown Skagway.

December 2014

Released by

STATE OF ALASKA

DEPARTMENT OF NATURAL RESOURCES

Division of Geological \& Geophysical Surveys

3354 College Rd.

Fairbanks, Alaska 99709-3707

$\$ 2.00$ 

Project contact: Amy Macpherson, GISP

Alaska EARTHQuAKe Center

University of Alaska Fairbanks

903 Koyukuk Street

Fairbanks, AK 99775

Phone: 907-474-7460

E-mail: aemacpherson@alaska.edu

Website: http://www.aeic.alaska.edu/

\section{Abbreviations used in this report:}

\begin{tabular}{|l|l|}
\hline AEC & Alaska Earthquake Center (www.aeic.alaska.edu) \\
\hline ASGDC & Alaska State Geo-Spatial Data Clearinghouse \\
\hline CAD & Computer Automated Drafting (software) \\
\hline DCRA & Division of Community and Regional Affairs \\
\hline DEM & Digital elevation model \\
\hline DNR & Alaska Department of Natural Resources \\
\hline ENC & Electronic Navigational Chart \\
\hline GINA & Geographic Information Network of Alaska \\
\hline GIS & Geographic Information System \\
\hline GPS & Geographic Positioning System \\
\hline NAD83 & North American Datum of 1983 \\
\hline NAVD88 & North American Vertical Datum of 1988 \\
\hline NED & National Elevation Dataset \\
\hline NGDC & National Geophysical Data Center \\
\hline NOAA & National Oceanic and Atmospheric Administration \\
\hline NOS & National Ocean Service \\
\hline NTHMP & National Tsunami Hazard Mapping Program \\
\hline OCS & Office of Coast Survey \\
\hline RTK & Real-time kinematic \\
\hline UAF & University of Alaska Fairbanks \\
\hline USACE & U.S. Army Corps of Engineers \\
\hline WGS84 & World Geodetic System of 1984 \\
\hline
\end{tabular}





\title{
DIGITAL ELEVATION MODELS OF SKAGWAY AND HAINES, ALASKA: PROCEDURES, DATA SOURCES, AND QUALITY ASSESSMENT
}

\author{
by \\ A.E. Macpherson, D.J. Nicolsky, and E.N. Suleimani \\ Alaska Earthquake Center, University of Alaska Fairbanks
}

\section{Introduction}

In May 2014 the Geophysical Institute at the University of Alaska Fairbanks (UAF) developed integrated bathymetric-topographic digital elevation models (DEMs) of Skagway and Haines, Alaska, for the National Tsunami Hazard Mitigation Program (NTHMP). The DEMs are designed to fit within a nested hierarchy of similar DEMs of larger spatial extent but coarser resolution. The gridded DEMs will be used to support modeling of tsunami generation, propagation, and inundation. This report describes the various source datasets, data processing tasks and techniques, the surface interpolation, and quality assessment of the seamless 8/15-arc-second ( $15 \mathrm{~m})$ bathymetric-topographic DEMs.

\section{Study Area}

The communities of Skagway (fig. 1) and Haines (fig. 2) are located in the northern part of the Alaska Panhandle-northeast of Glacier Bay National Park and Preserve, and in the northernmost fjord on the Inside Passage on the south coast of Alaska, respectively (fig. 3). The combined population is around 2,700. The communities are just south of the Canada-United States border at British Columbia and about 600 air miles southeast of Anchorage. Skagway is set in a narrow, glaciated valley at the head of Taiya Inlet at the northernmost end of Lynn Canal. Haines is 45 minutes by ferry south from Skagway, on the shores of the Lynn Canal between the Chilkoot and Chilkat rivers.

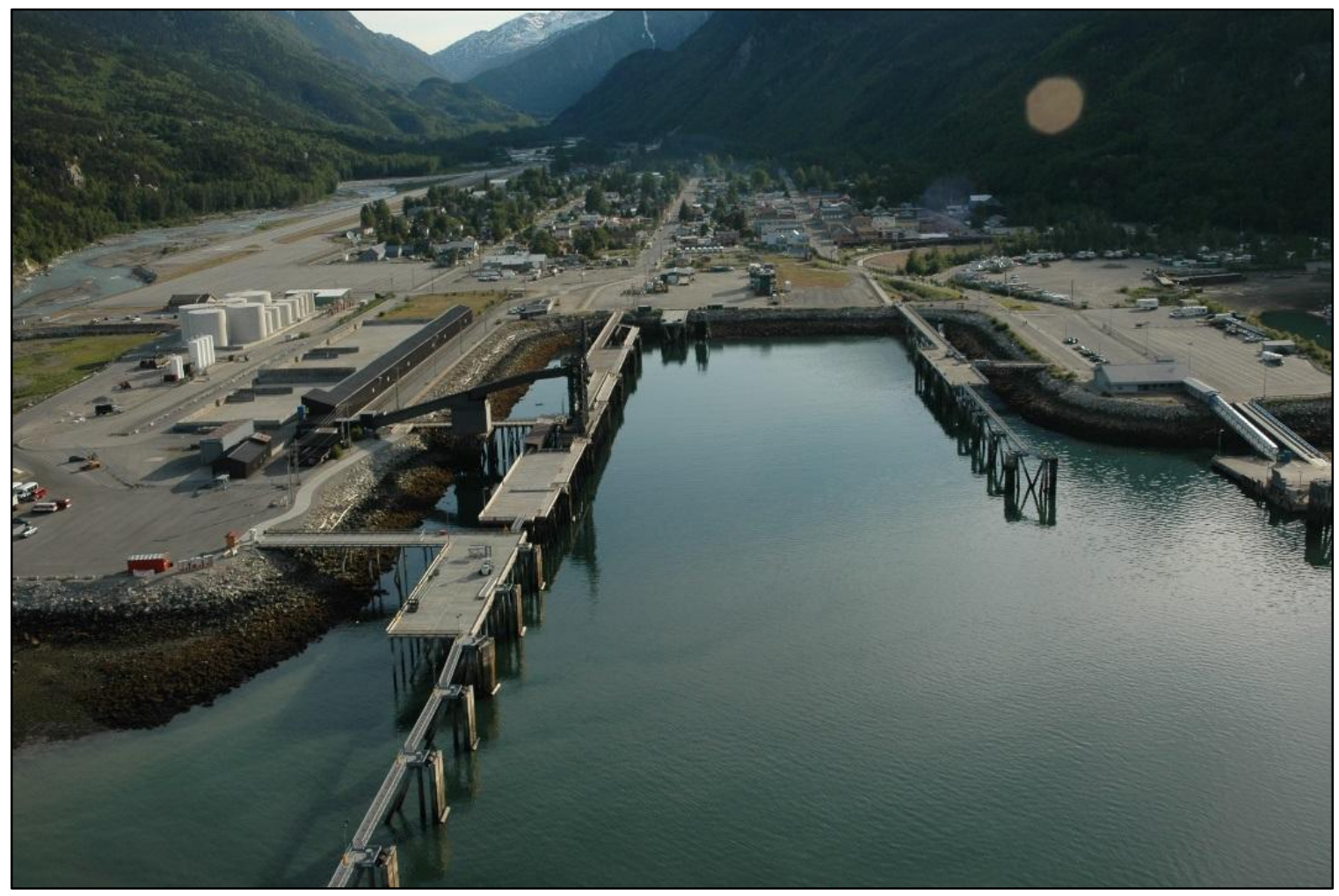

Figure 1. View of the community of Skagway, Alaska. Photo source: http://alaskafisheries.noaa.gov/mapping/szflex/ 


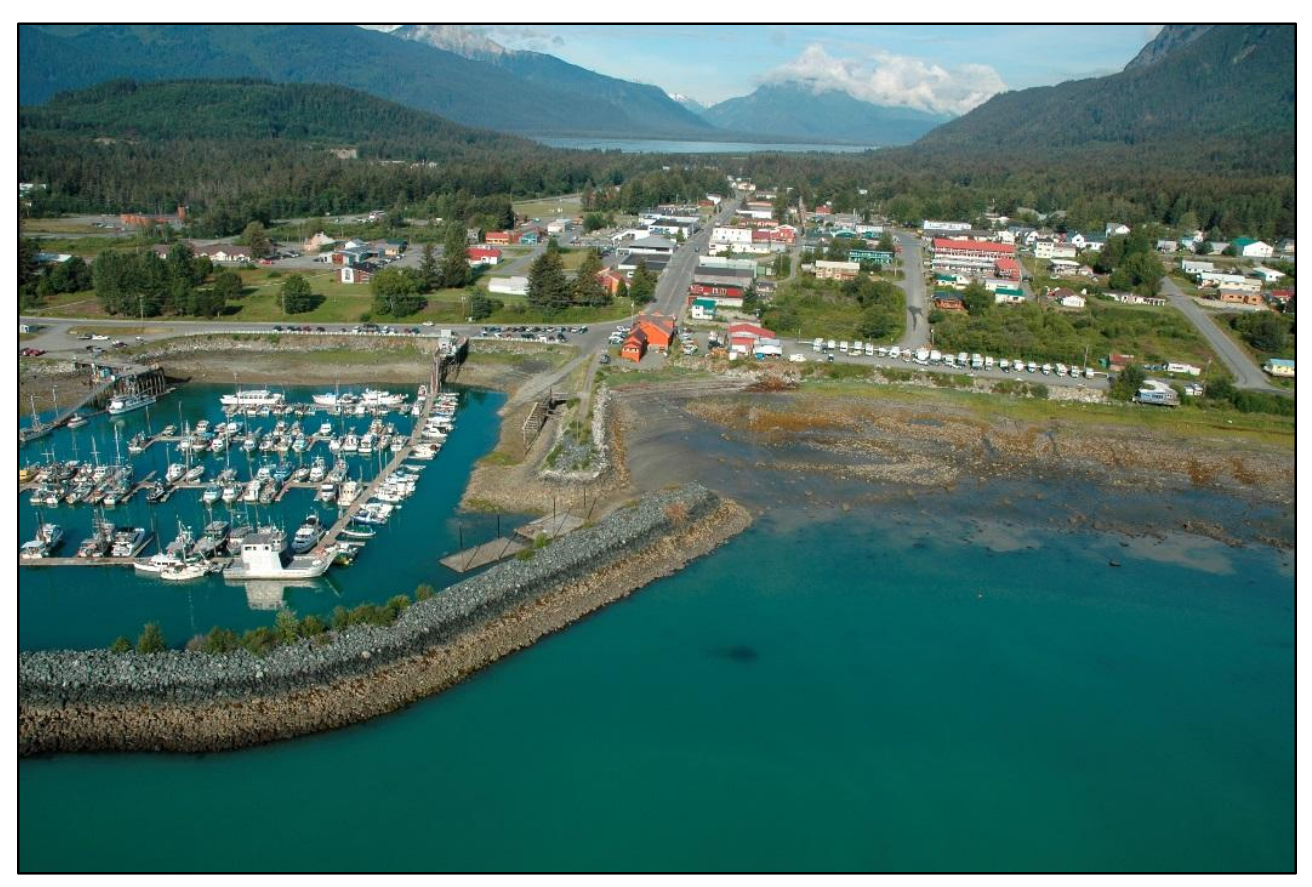

Figure 2. View of the community of Haines from the southeast. Photo source: http://alaskafisheries.noaa gov/mapping/szflex/

An 8/3-arc-second DEM ( $80 \mathrm{~m}$ ) developed by The National Geophysical Data Center (NGDC) (Caldwell and others, 2012) encompasses the communities of Haines and Skagway. We developed the 8/15-arc-second grid to cover Haines and Skagway for use in numerical modeling of tsunamis and the mapping of tsunami inundation zones for both cities.

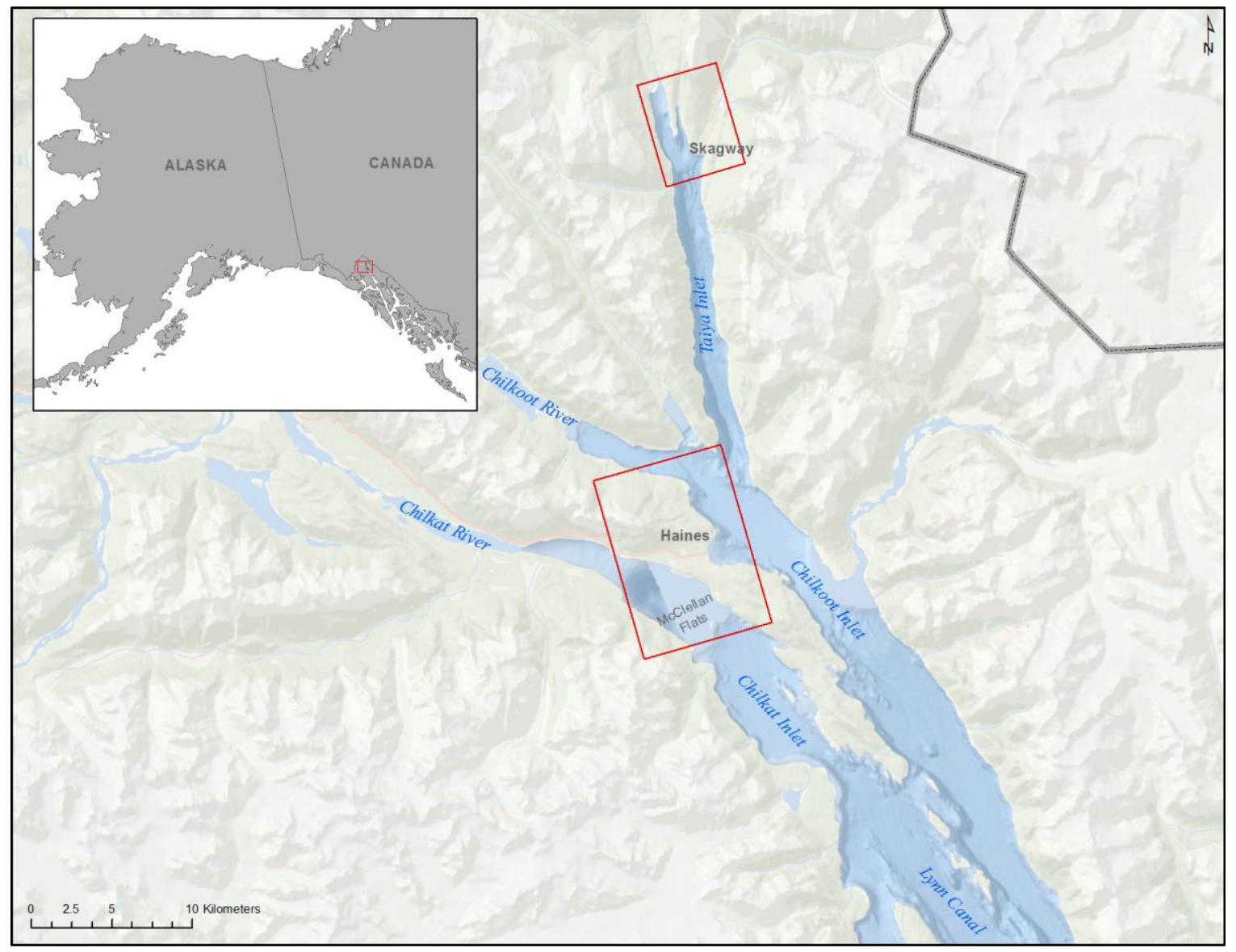

Figure 3. Map showing study areas in Southeast Alaska, with extents of the 8/15-arc-second DEMs delineated with red boxes. 


\section{DEM Specifications}

The Skagway and Haines 8/15-arc-second DEMs are designed to simulate the tsunami run-up for each community; their specifications can be found in table 1. Figure 3 shows the locations and spatial extents of the DEMs.

Table 1. Specifications for the nested Skagway and Haines, Alaska, DEMs

\begin{tabular}{|c|c|c|}
\hline & Skagway, Alaska & Haines, Alaska \\
\hline Cell Size & \multicolumn{2}{|c|}{ Coverage Area } \\
\hline $8 / 15$-arc-second & $\begin{array}{c}135.54^{\circ} \text { to } 135.395^{\circ} \mathrm{W} \\
59.291^{\circ} \text { to } 59.188^{\circ} \mathrm{N}\end{array}$ & $\begin{array}{c}135.284^{\circ} \text { to } 135.374^{\circ} \mathrm{W} \\
59.437^{\circ} \text { to } 59.495^{\circ} \mathrm{N}\end{array}$ \\
\hline Coordinate system & \multicolumn{2}{|c|}{ Geographic decimal degrees } \\
\hline Horizontal Datum & \multicolumn{2}{|c|}{ World Geodetic System 1984 (WGS84) } \\
\hline Vertical Datum & \multicolumn{2}{|c|}{ Mean Higher High Water (MHHW) (Skagway, 2007-2011 } \\
\hline Vertical Units & \multicolumn{2}{|l|}{ meters } \\
\hline Grid Format & \multicolumn{2}{|l|}{ ASCII raster grid } \\
\hline
\end{tabular}

Following established NGDC procedures, we collected datasets covering an area 5 percent greater than the DEM boundary because interpolation algorithms are prone to interpolation error along data boundaries where there are data points on one side of the boundary but not on the other. We clipped the output surface to the DEM boundary after the final interpolation to trim off potential interpolation errors that may exist along the margins of the grid.

\section{Data Sources and Processing}

\section{Coastlines}

Placement of the coastline is one of the most important components of coastal DEM development. This is especially true for the purpose of tsunami inundation mapping because the coastline separates two essentially different types of datasets: topography and bathymetry.

Digital MHW coastline positions were extracted from National Oceanic and Atmospheric Administration's (NOAA's) Office of Coast Survey (OCS) ENC (Electronic Navigational Chart) Direct-to-GIS online extraction service $^{1}$. A cartographic coastline dataset created by the Alaska Department of Natural Resources, Information Resource Management Section, at a scale of 1:63,3602, was downloaded from the Alaska State Geo-Spatial Data Clearinghouse (ASGDC). The coastlines were compared and edited to match high-resolution imagery and topographic data provided by the Alaska Mapped ${ }^{3}$ program and the Geographic Information Network of Alaska's (UAF-GINA's's) Best Data Layer Web Mapping Service ${ }^{5}$ to create a final coastline product. The ENC coastline conformed most closely to the imagery but did contain some gaps that required manual, heads-up digitizing from the imagery at a scale of roughly 1:3,000. Figure 4 shows a comparison of the original source coastlines and the final edited coastline.

\footnotetext{
${ }^{1}$ http://www.nauticalcharts.noaa.gov/csdl/ctp/encdirect new.htm

${ }^{2}$ http://dnr.alaska.gov/mdfiles/alaska 63360.html

${ }^{3}$ http://www.alaskamapped.org

${ }^{4}$ http://www.gina.alaska.edu

${ }^{5}$ http://wms.alaskamapped.org/bdl? 


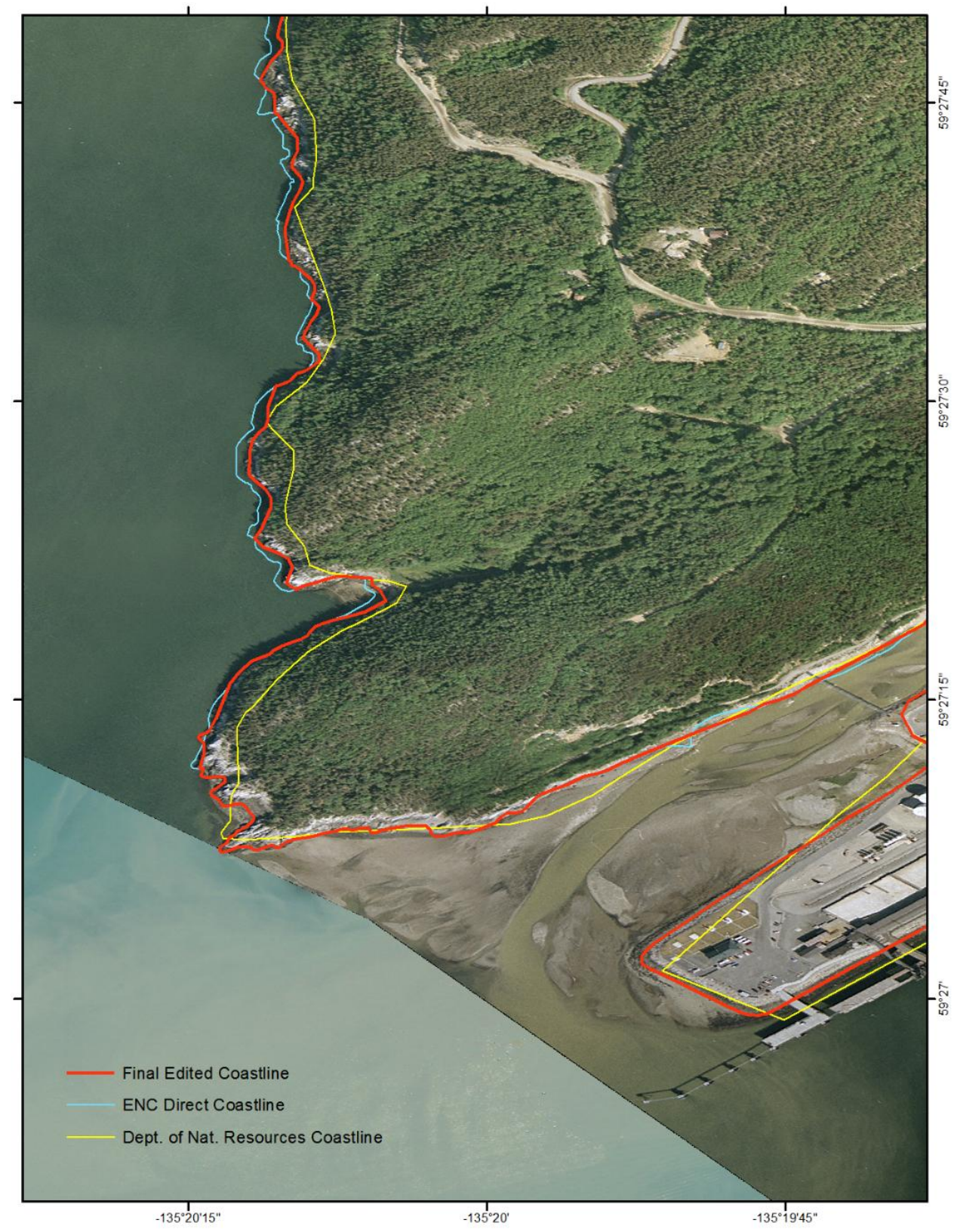

Figure 4. Skagway digital coastline datasets comparison. ENC Direct coastline is displayed in light blue, Department of Natural Resources coastline in yellow, and the final edited coastline is in red.

\section{Bathymetry}

In addition to the coastline datasets, we assembled various bathymetric data. Table 2 lists the bathymetry data used in the compilation of the Skagway and Haines DEMs including NOS (National Ocean Service) hydrographic surveys, NOAA ENC soundings, and U.S. Army Corps of Engineers (USACE) harbor surveys. ENC sounding data were extracted from the Office of Coast Survey's ENC Direct-to-GIS online extraction service. NGDC multi-beam survey data and NOS point soundings were downloaded as XYZ point data from the NGDC NEXT system ${ }^{6}$ or 'Point Store'. One NGDC trackline survey ${ }^{7}$ was located; it was dated 1965 and was in an area populated with more recent surveys, thus this trackline survey was not used. We discovered one NGDC multibeam survey dataset but it was not used in the creation of the DEMs because it did not add any new information to the grid (the area is well covered by high-resolution data). Figures 5 and 6 show the coverage of these various datasets for Skagway and Haines.

\footnotetext{
${ }^{6}$ http://www.ngdc.noaa.gov/next-web/cart.html

${ }^{7}$ http://maps.nqdc.noaa.qov/viewers/geophysics-1.7/
} 
Table 2. Bathymetric data sources used in creation of Skagway and Haines DEMs.

\begin{tabular}{|l|l|l|c|c|c|}
\hline \multicolumn{1}{|c|}{ Source } & \multicolumn{1}{|c|}{ Date } & \multicolumn{1}{|c|}{ Data Type } & Spatial Resolution & \multicolumn{1}{c|}{ Horizontal Datum } & $\begin{array}{c}\text { Vertical } \\
\text { Datum }\end{array}$ \\
\hline NOAA NOS & $1943-2000$ & Hydrographic survey soundings & $1: 2,000$ to $1: 10,000$ & NAD83 geographic & MLLW \\
\hline NOAA OCS & 2004 & ENC extracted soundings & $1: 40,000$ & WGS84 geographic & MLLW \\
\hline USACE & $2000 / 2008$ & $\begin{array}{l}\text { Multi-beam hydrographic } \\
\text { surveys }\end{array}$ & $\sim 3 \mathrm{~m}$ pt spacing & NAD83 SP Zone 1 (ft) & MLLW \\
\hline
\end{tabular}

Bathymetric data were transformed to WGS84 and MHHW datums as needed. Where recent, higherresolution data exist, older data were ignored. Vertical datum transformations were conducted with a solestation offset based on the NOAA tide station (tidal station \# 9452400) in Skagway (table 3). Because Haines is in close proximity to Skagway, connected by deep water, and has no independent tide station, we infer the local MHHW datum for Skagway as a best-available approximation for the local MHHW datum in Haines.

Table 3. Relationship between MHHW, MLLW, and NAVD88 datums at the Skagway tidal station \#9452400 for the 20072011 modified tidal epoch.

\begin{tabular}{|c|c|}
\hline Vertical Datum & Difference to MHHW (meters) \\
\hline MHHW & 0 \\
\hline MLLW & 5.101 \\
\hline NAVD88 & -3.86 \\
\hline
\end{tabular}

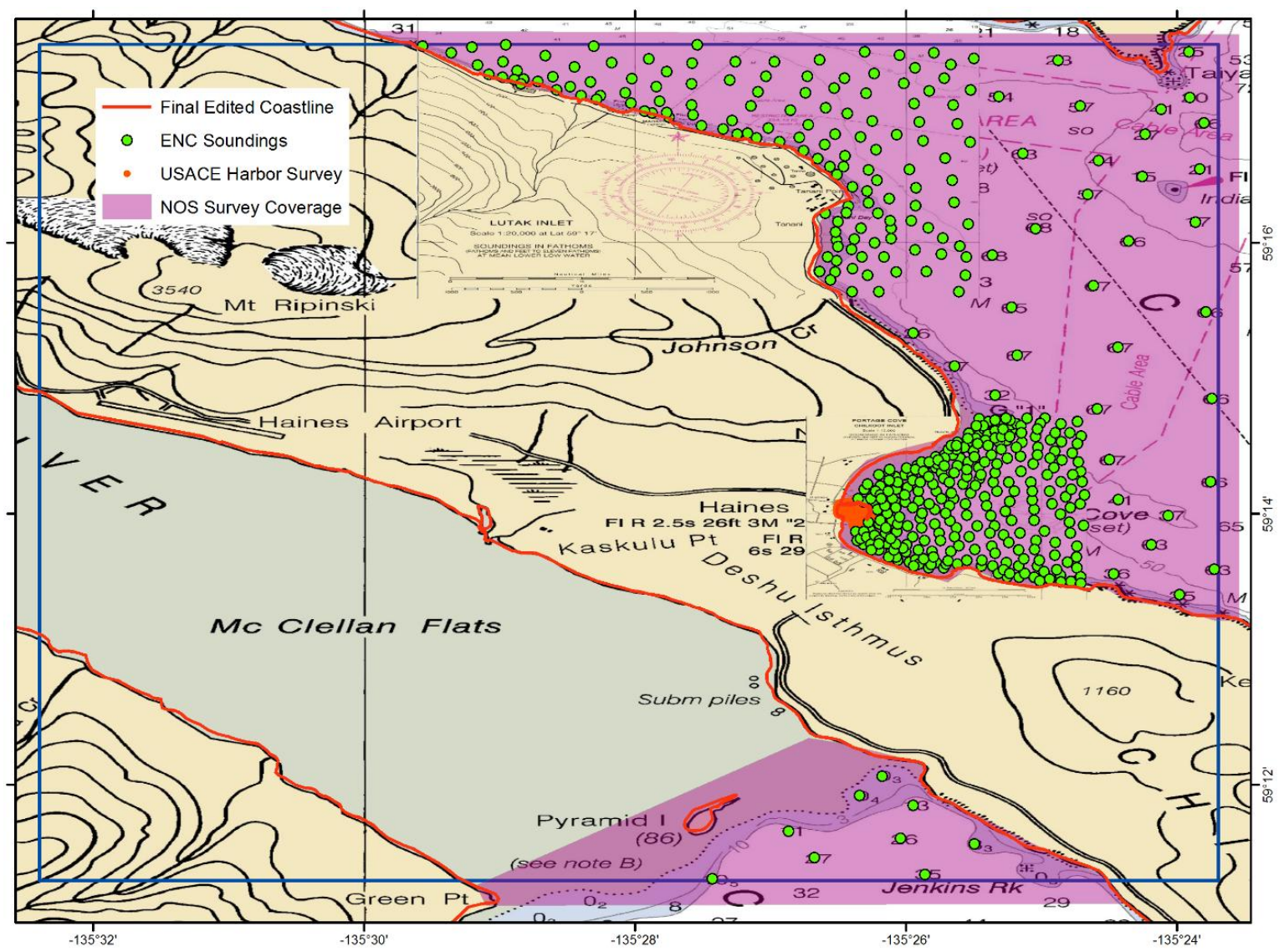

Figure 5. Coverage of bathymetric datasets for Haines DEM. McClellan Flats elevations derived from existing NOAA DEM at 8/3-arc-second resolution and edited to more smoothly transition to the boundary with NOS survey data and topographic data. Basemap: NOAA RNC Image Service. 


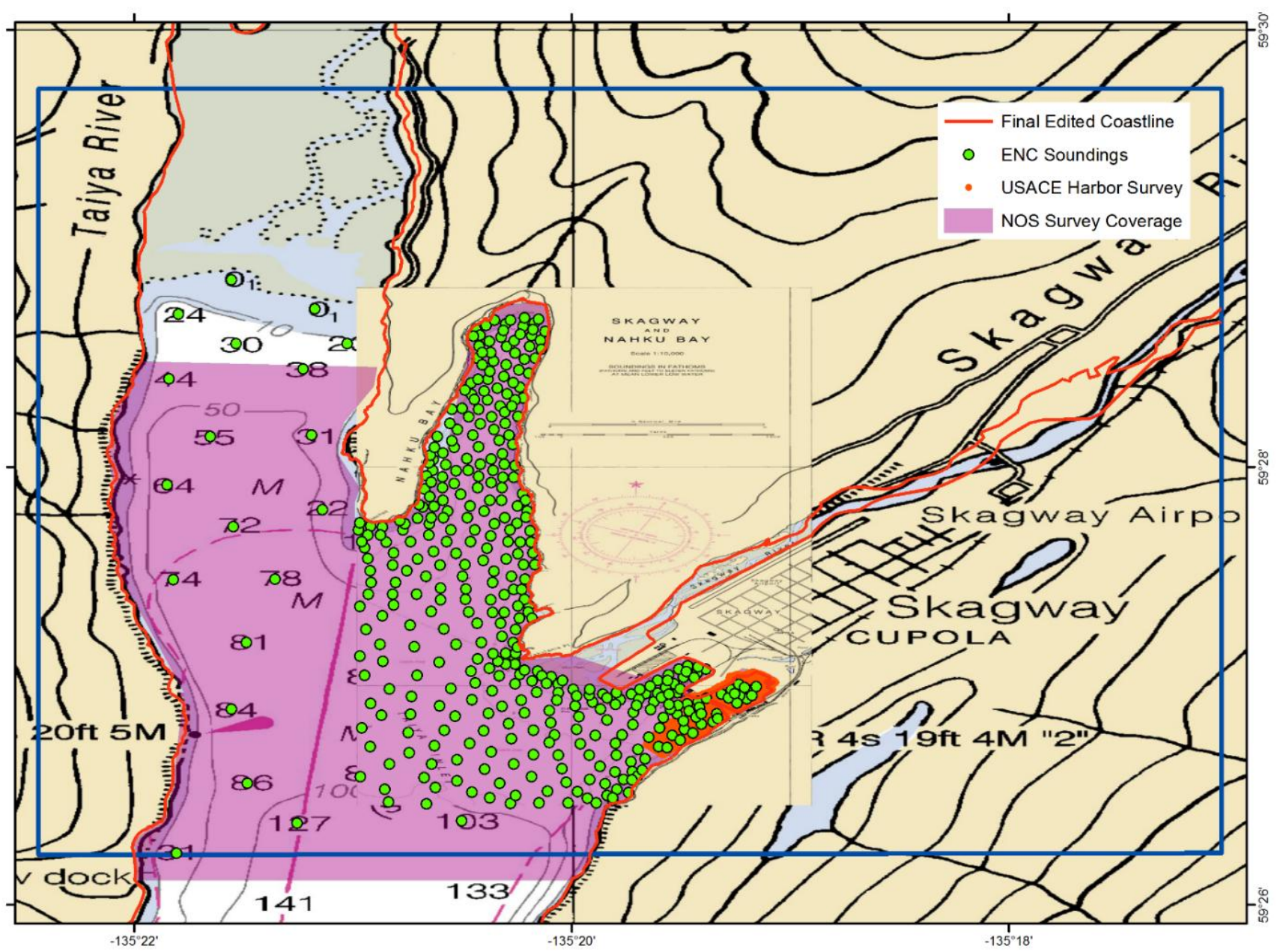

Figure 6. Coverage of bathymetric datasets for Skagway DEM. Basemap: NOAA RNC Image Service.

\section{Topography}

We evaluated several sources of topographic data for use in this project. Topographic data used in developing the Skagway and Haines DEMs is listed in table 4. Alaska's Division of Community and Regional Affairs (DCRA) provided topographic data for Skagway. No comparable DCRA dataset exists for Haines and further research did not reveal any other topographic data. A $5 \mathrm{~m}$ IfSAR dataset was also available for this region but not utilized due to a lack of accuracy statistics for the data covering this region. ArcGIS was used to transform the CAD files to shapefiles. The National Elevation Dataset (NED) DEM provided full topographic coverage at 1/3-arc-second. Vertical datum transformations were based on the NOAA tide station in Skagway (table 3).

Table 4. Topographic data sources used in creation of Skagway and Haines DEMs

\begin{tabular}{|l|c|c|c|l|c|}
\hline \multicolumn{1}{|c|}{ Source } & Date & Data Type & Spatial Resolution & \multicolumn{1}{|c|}{ Horizontal Datum } & $\begin{array}{c}\text { Vertical } \\
\text { Datum }\end{array}$ \\
\hline DCRA (Skagway only) & 2004 & CAD & $<1$ meter & NAD83 SP Zone 1 (Ft) & NAVD88 \\
\hline $\begin{array}{l}\text { National Elevation Dataset } \\
\text { (NED) }\end{array}$ & Various & DEM & $1 / 3$-arc-second & WGS84 Geographic & NAVD88 \\
\hline UAF & 2013 & GPS Points & & WGS84 Geographic & MHHW \\
\hline
\end{tabular}




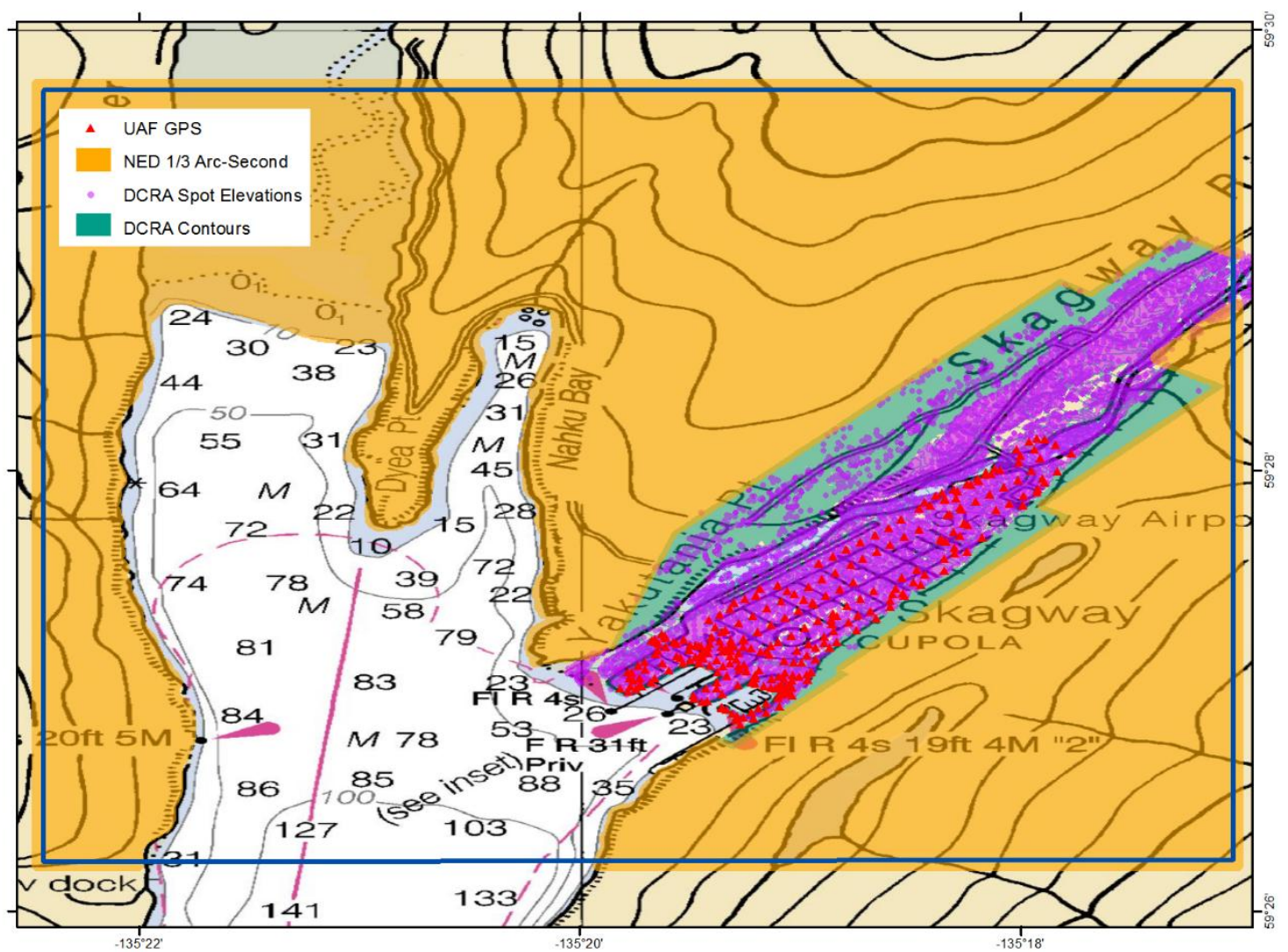

Figure 7. Coverage of topographic datasets for Skagway DEM.

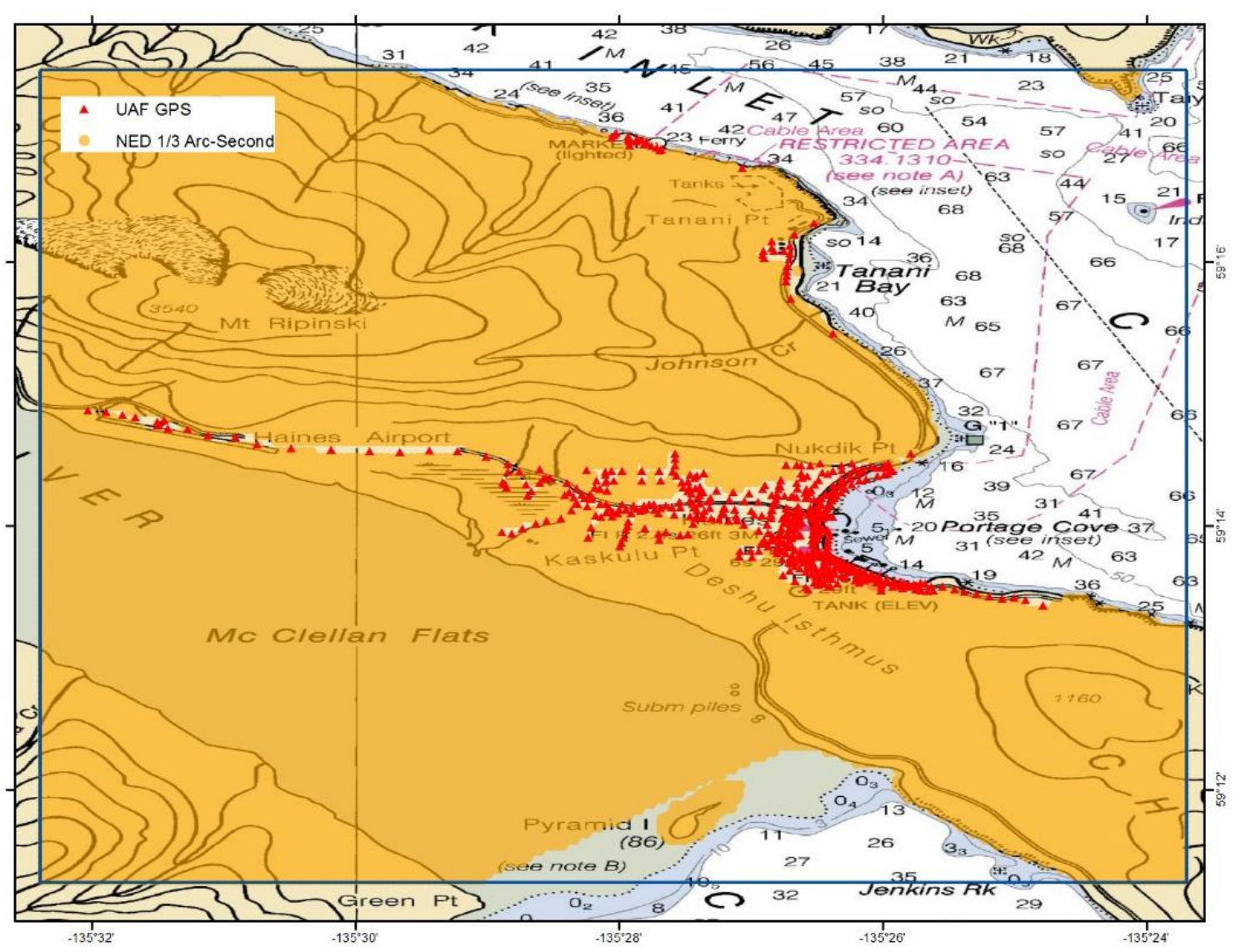

Figure 8. Coverage of topographic datasets for Haines DEM. 


\section{RTK GPS Data Collection}

The available topographic datasets are augmented with a real-time kinematic (RTK) GPS survey in the harbor areas and along nearshore areas in Skagway and Haines. The survey in Skagway was conducted October 1820, 2013, and the survey in Haines October 22-24, 2013. The collected GPS measurements had 0.03-0.05 m (1.2-2 in) horizontal and vertical accuracy with respect to the base station (Leica Geosystems AG, 2002). To achieve sub-meter accuracy for all GPS measurements relative to the MHHW datum, the base station must be linked to the MHHW datum with sub-meter accuracy. This level of accuracy can be achieved if the base station is set up at an established tidal benchmark with a known geodetic elevation. No conveniently located tidal benchmark was available in Skagway for this survey, and there are no listed tidal benchmarks in Haines $^{8}$. Therefore, we used the technique described below to convert the collected GPS measurements to the MHHW datum.

During the survey, we took GPS measurements of the sea surface height at a partially enclosed location-the city harbor-where the water was relatively still; the location is shown by the red arrow in figure 9A. The sea level was measured at low and high tides as well as at some intermediate tide stages. This provides a measured tide level $\left(\mathrm{H}_{2}\right)$ known relative to the base station datum at some instance of time $\left(t_{\mathrm{k}} ; k=\right.$ the index number of the sea level measurement) with an accuracy of several centimeters.

The tide level, $\mathrm{H}_{1}(\mathrm{t})$, with respect to the MHHW datum is observed every six minutes at the NOAA tide station in Skagway. Therefore, we calculated the vertical shift between the MHHW datum and the base station datum by finding the difference (least squares method) between the GPS-measured sea level, $\mathrm{H}_{2}$, and the NOAAobserved sea level, $\mathrm{H}_{1}$, at the instances $t_{\mathrm{k}}$. The results of the least-square fitting for Skagway are shown in figure 9B. Note that the vertical shift incorporates both the height of the water level above the WGS84 ellipsoid and the positional error of the GPS base station. This shift value was applied to all collected GPS data to convert each survey measurement to the MHHW datum. The vertical shift calculated for Skagway was $-8.0 \mathrm{~m}$, while the shift for Haines was $-9.8 \mathrm{~m}$.

We evaluated the accuracy of our converted GPS data with respect to the MHHW level by estimating the MHHW elevation for tidal benchmark '945 2400 C 1982' in Skagway. This benchmark does not have a published elevation relative to the current, modified 2007-2011 tidal epoch; however, for the superseded 1960-1978 tidal epoch its published elevation was 3.309 m above MHHW. Direct measurement of other tidal benchmarks during the survey was hampered by equipment access limitations. We estimate an elevation of disk ' 9452400 C 1982', as follows. First, we find the difference in the MHW elevation of five available benchmarks in Skagway between the superseded and present tidal epochs. It appears that these benchmarks were uniformly uplifted relative to the tidal datum by $0.244 \pm 0.002 \mathrm{~m}$. By applying this vertical shift to disk '945 2400 C 1982', we estimate that its elevation at the present tidal epoch is $3.553 \mathrm{~m}$ above MHHW.

Measurement of benchmark ' 9452400 C 1982' during the GPS survey calculated with the -8.0 m vertical shift was $3.383 \mathrm{~m}$ above MHHW. The $0.17 \mathrm{~m}$ difference between the estimated elevation and the elevation based on the calibrated shift demonstrates that our method provides sub-meter accuracy in Skagway. A similar technique was previously applied at other locations across Alaska and the reported difference between the assessed and NOAA-stamped elevation of the benchmark was approximately the same as the difference estimated in this report (Nicolsky and others, in review [Fox Island]; Nicolsky and others, in review [City of Sand Point]). To convert the survey points in Haines, we employed the same technique. The collected GPS measurements are reported in the WGS84 horizontal datum, with a horizontal accuracy of approximately 35 m (10-16 ft) (Leica Geosystems AG, 2002).

${ }^{8}$ http://tidesandcurrents.noaa.qov

MP 155 


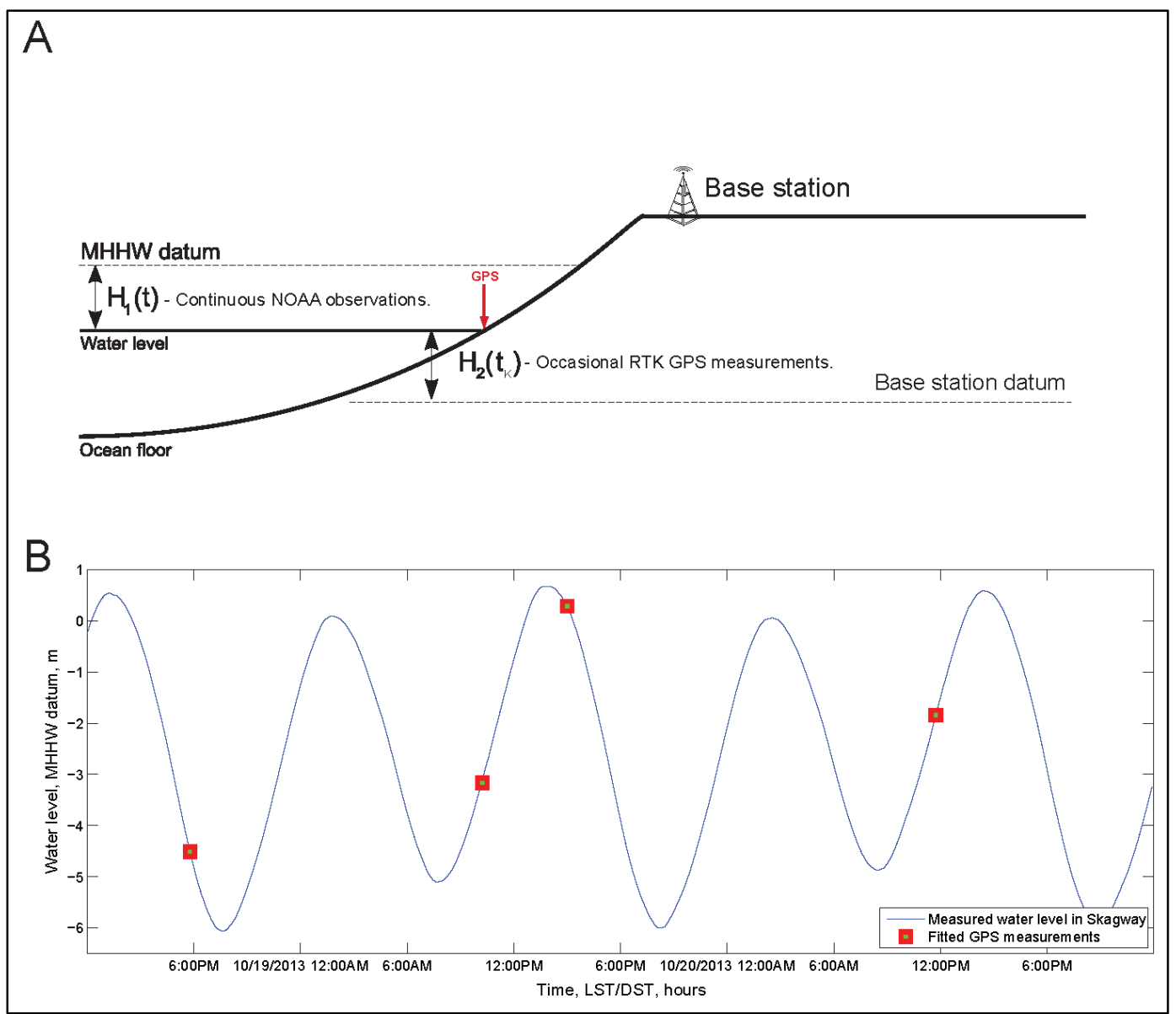

Figure 9. A. Measurement of sea level in the MHHW datum and the relation of the base station datum to the MHHW datum. B. Predicted water-level dynamics in Skagway and the fitted GPS measurements of the water level in the MHHW datum.

\section{DEM Development}

After horizontal and vertical transformations were applied in ArcGIS, the resulting ESRI shapefiles were reviewed in ArcMap and QT Modeler for consistency among datasets. Problems and errors were identified and resolved before proceeding with subsequent gridding steps. Some fixes and preliminary steps included:

- Where there were inconsistent, overlapping bathymetry and topography datasets, older data were clipped to newer data and only used in those areas where gaps in newer data coverage existed.

- The NED topographic data were clipped to the adjusted ENC coastline. A careful visual inspection of the bathymetric/topographic interface was conducted to ensure there were no artificial cliffs in the DEM. This area displays a rugged coastline with some steep cliffs along the shore and the DEM was inspected to confirm these also appeared correctly in the final dataset.

- Bathymetric data were lacking in the delta region of McClellan mudflats, so MHW elevations were pulled from existing NOAA DEM at 8/3-arc-second resolution, transformed, and edited to more smoothly transition to the boundary with NOS survey data and topographic data. The central flat area was adjusted to zero elevation and then interpolated toward the coast and deeper waters where survey data existed.

- Elevations at Haines Airport runway were adjusted minimally (less than $1 \mathrm{~m}$ ) to match documented survey ${ }^{9}$ elevations.

${ }^{9}$ https://nfdc.faa.qov/nfdcApps/airportLookup/airportDisplay.jsp?category=nasr\&airportld=HNS 
We used the shapefiles discussed in the preceding sections of this report as input into the Tensioned Spline function of ArcGIS' Spatial Analyst extension to construct the seamless bathymetric-topographic DEM. The Tensioned Spline tool performs a spline interpolation of input data-point values to create a raster dataset in which the surface passes exactly through the input $x-y-z$ data and interpolates values for cells with no data. A weight parameter of 1 was used in order to create a surface that closely fits the input control points. The use of this interpolation method conforms to techniques used for the creation of other NGDC DEM products (Caldwell and others, 2011).

\section{DEM Analysis}

The completed Skagway and Haines DEMs were visually compared to nautical charts, topographic maps, and high-resolution imagery. A color classification was applied to the seamless DEM to separate positive and negative values. The coastline was meticulously scrutinized with respect to both the final coastline vector data and high-resolution imagery in GINA's Best Data Layer Web Mapping Service. Final DEMs were reviewed in three-dimensional (3-D) space using Quick Terrain Modeler (Applied Imagery, 2013) software and ESRI ArcScene (ESRI, 2011) (figs. 10 and 11). The DEMs were also compared closely to the UAF GPS collection using a custom MatLab (The Mathworks, Inc., 2012) program to check for inconsistencies, to adjust contouring along the shore, and to improve the depiction of breakwaters and jetties where there were sparse source data points.

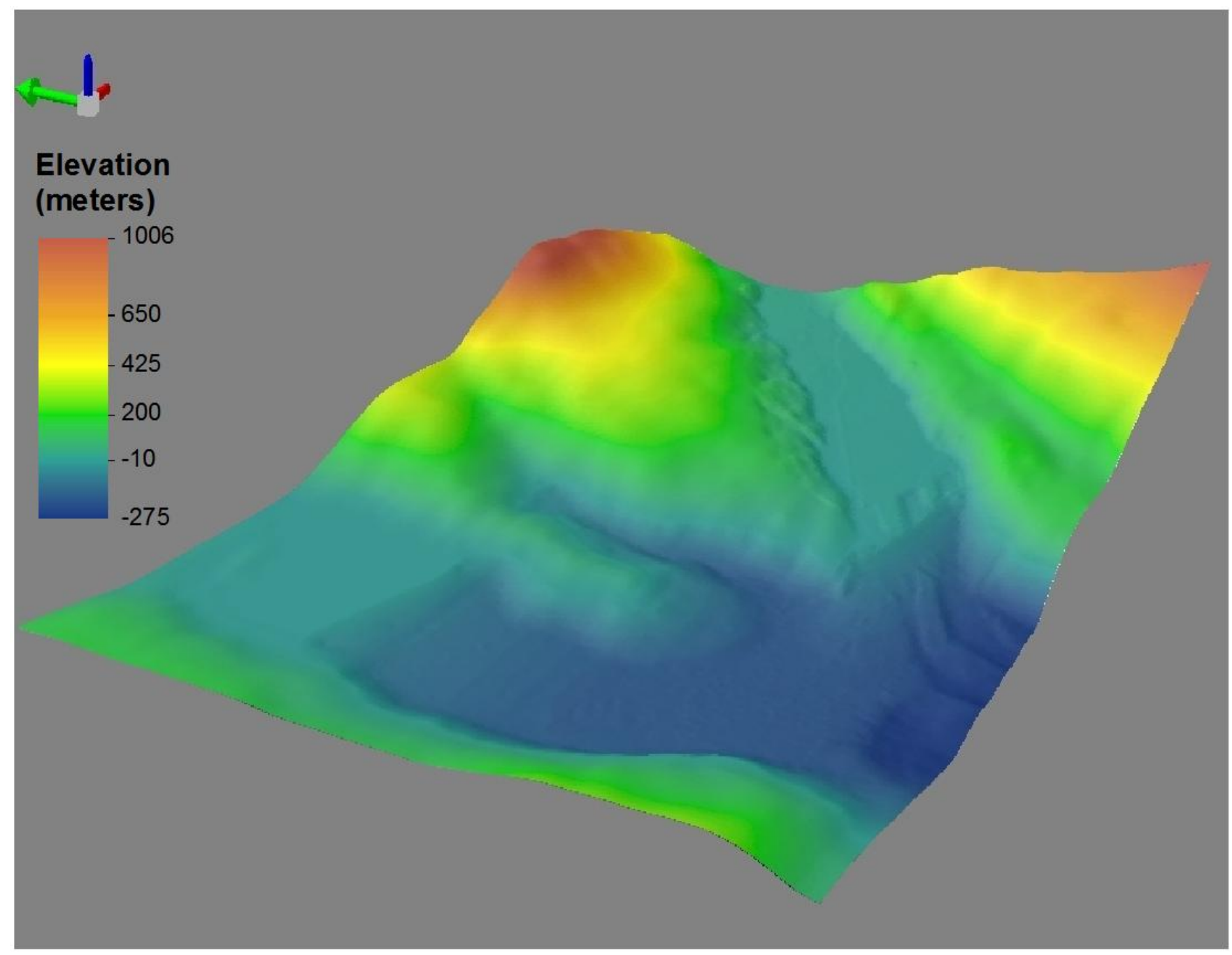

Figure 10. ESRI ArcScene 3-D view of Skagway DEM with hillshade. 


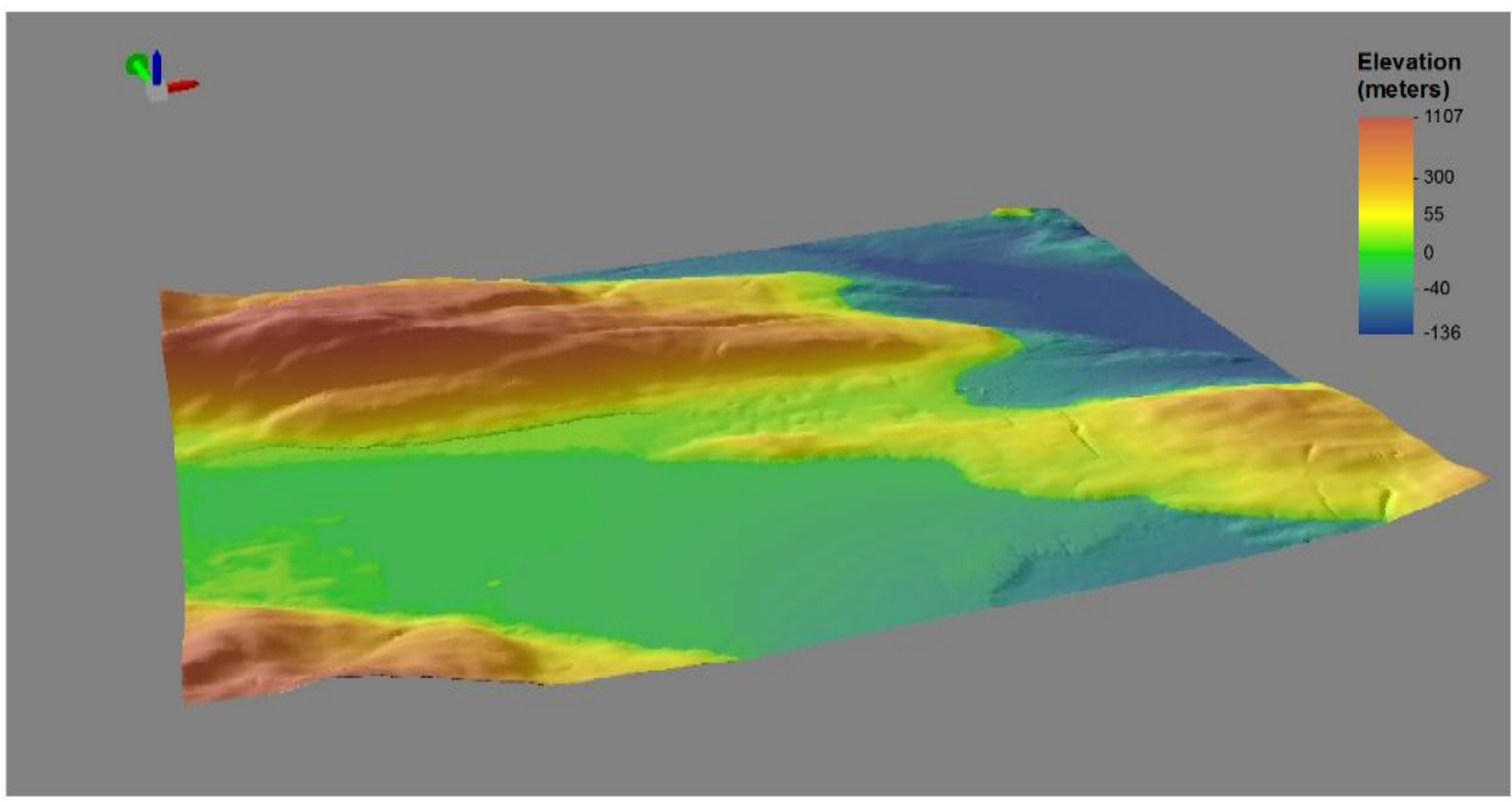

Figure 11. ESRI ArcScene 3-D view of Haines DEM with hillshade.

Finally, a comparison of the UAF-surveyed GPS points to the existing NGDC 8/3-Arc-Second DEM for Southeast Alaska versus the UAF GPS points as compared to the new Skagway and Haines DEMs shows a marked improvement for elevations at these surveyed areas. Histograms and specific summary statistics of these results are provided in figures 12-18. According to reports of similar coastal DEM developments, large outlier differences are often the result of more than one data point being averaged by the interpolation for a single grid cell, and mainly occur on steep bathymetric slopes (Caldwell and others, 2011).

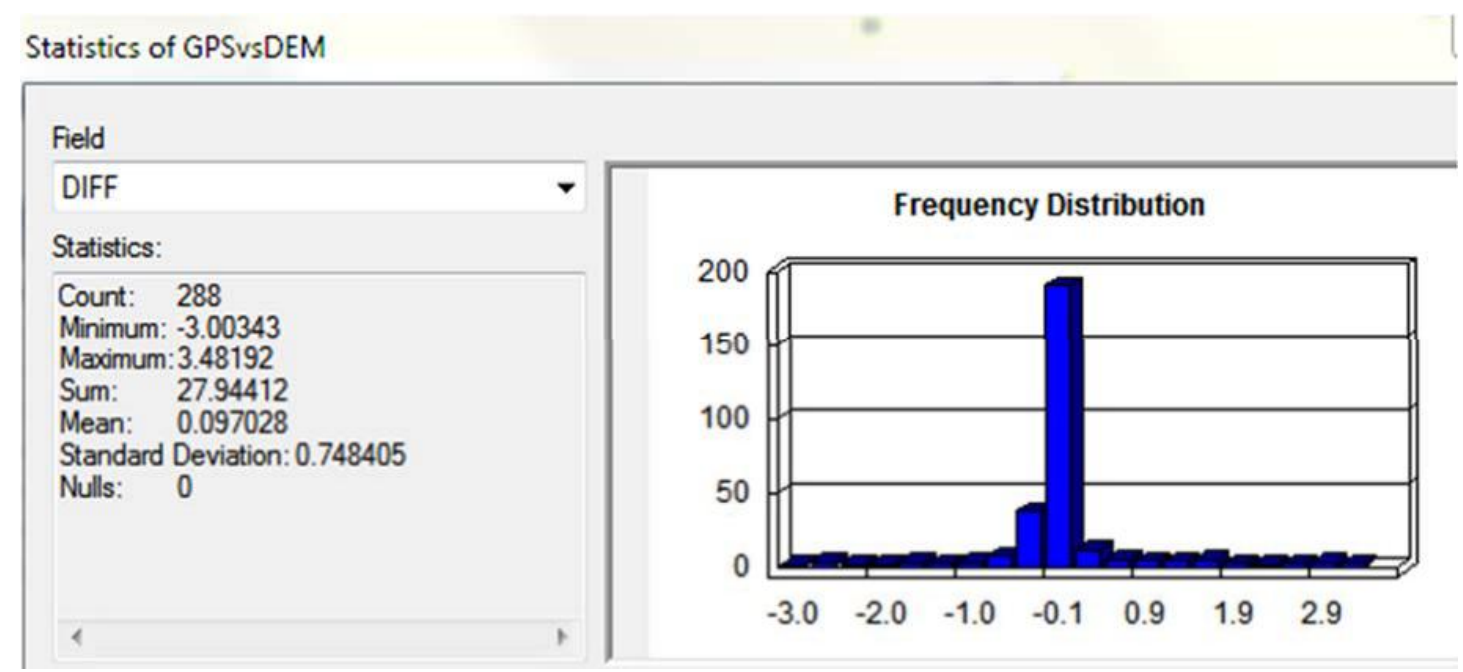

Figure 12. Comparison of UAF Skagway GPS points to new Skagway 8/15-arc-second DEM; mean offset is $0.097 \mathrm{~m}$ with a maximum offset of $3.48 \mathrm{~m}$. 
Statistics of GPSvsORIG

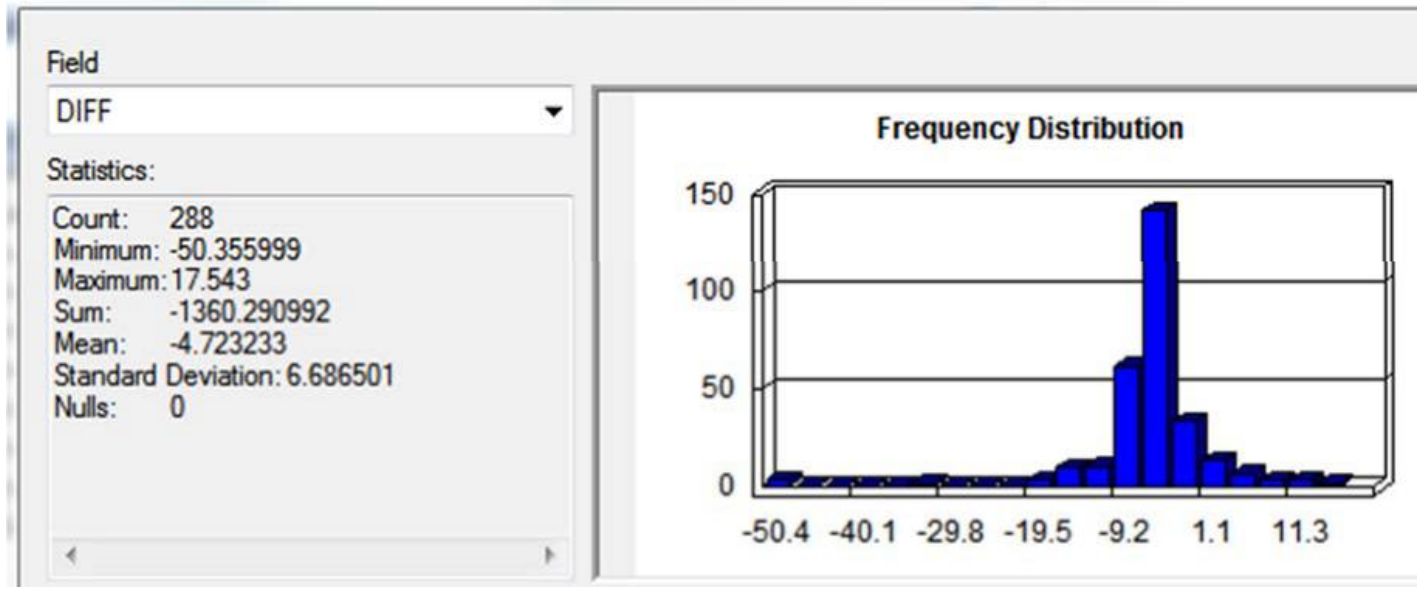

Figure 13. Comparison of UAF Skagway GPS points to 8/3-arc-second Southeast AK DEM; mean offset is $-4.723 \mathrm{~m}$ with a maximum offset of $-50.4 \mathrm{~m}$.

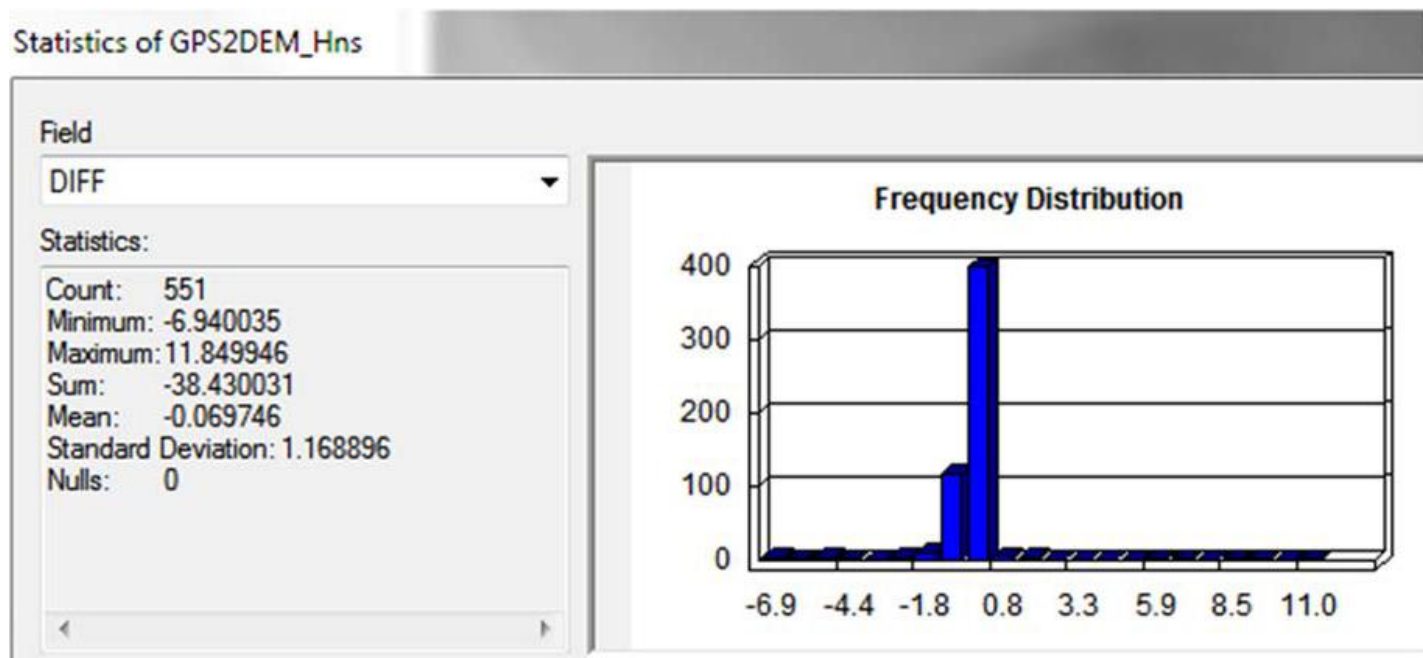

Figure 14. Comparison of UAF Haines GPS points to new Haines 8/15-arc-second DEM; mean offset is $-0.069 \mathrm{~m}$ with a maximum offset of $11.85 \mathrm{~m}$.

Statistics of GPS2ORig_Hns

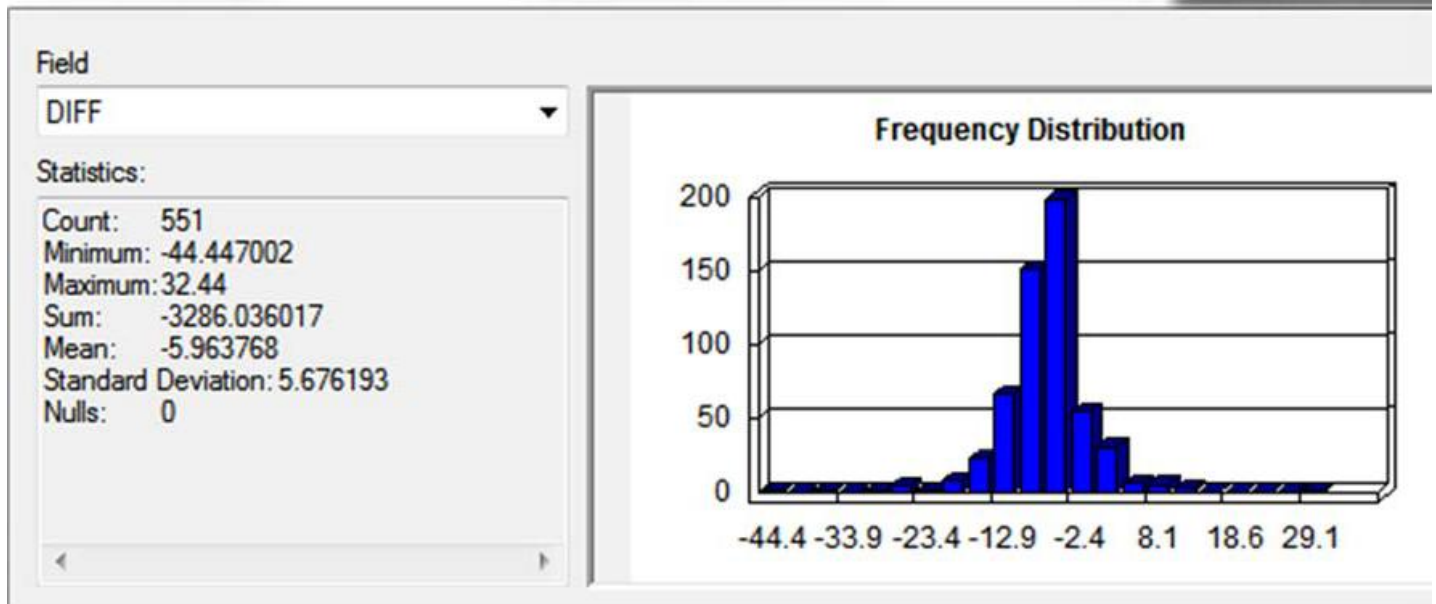

Figure 15. Comparison of UAF Haines GPS points to 8/3-arc-second Southeast AK DEM; mean offset is $-5.96 \mathrm{~m}$ with a maximum offset of $-44.44 \mathrm{~m}$. 


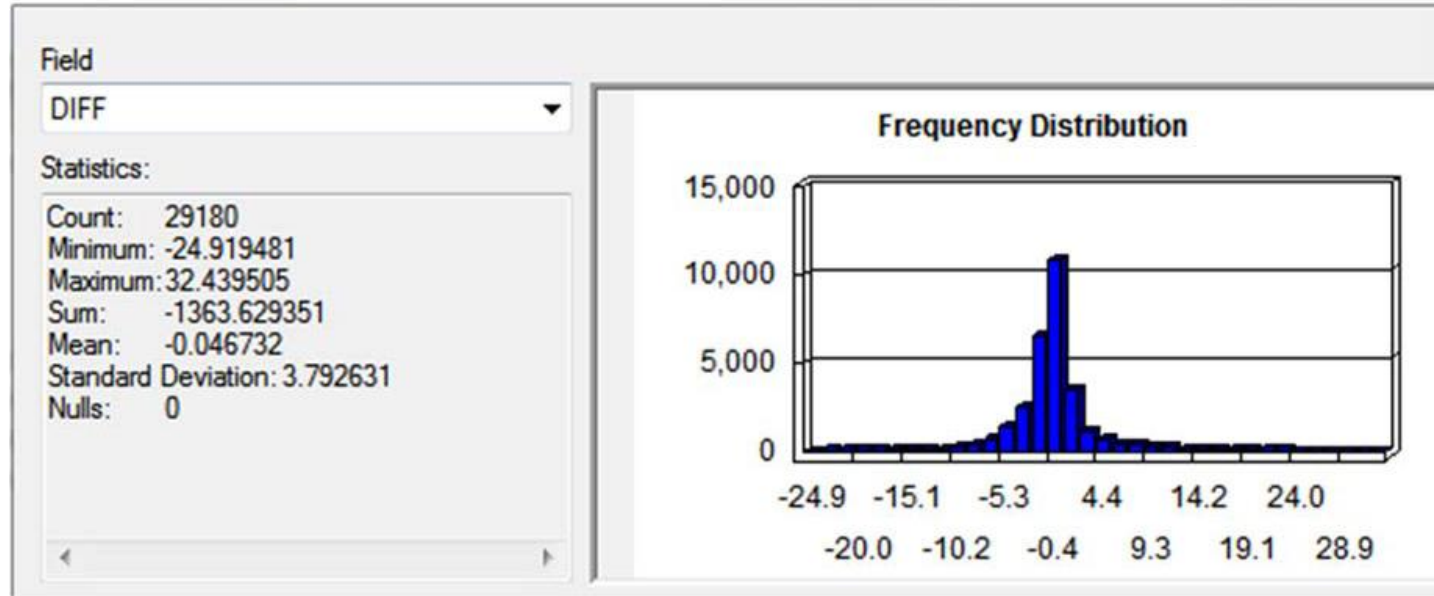

Figure 16 Comparison of NOS survey points to new Skagway 8/15-arc-second DEM; mean offset is $-0.047 \mathrm{~m}$ with a maximum offset of $32.44 \mathrm{~m}$.

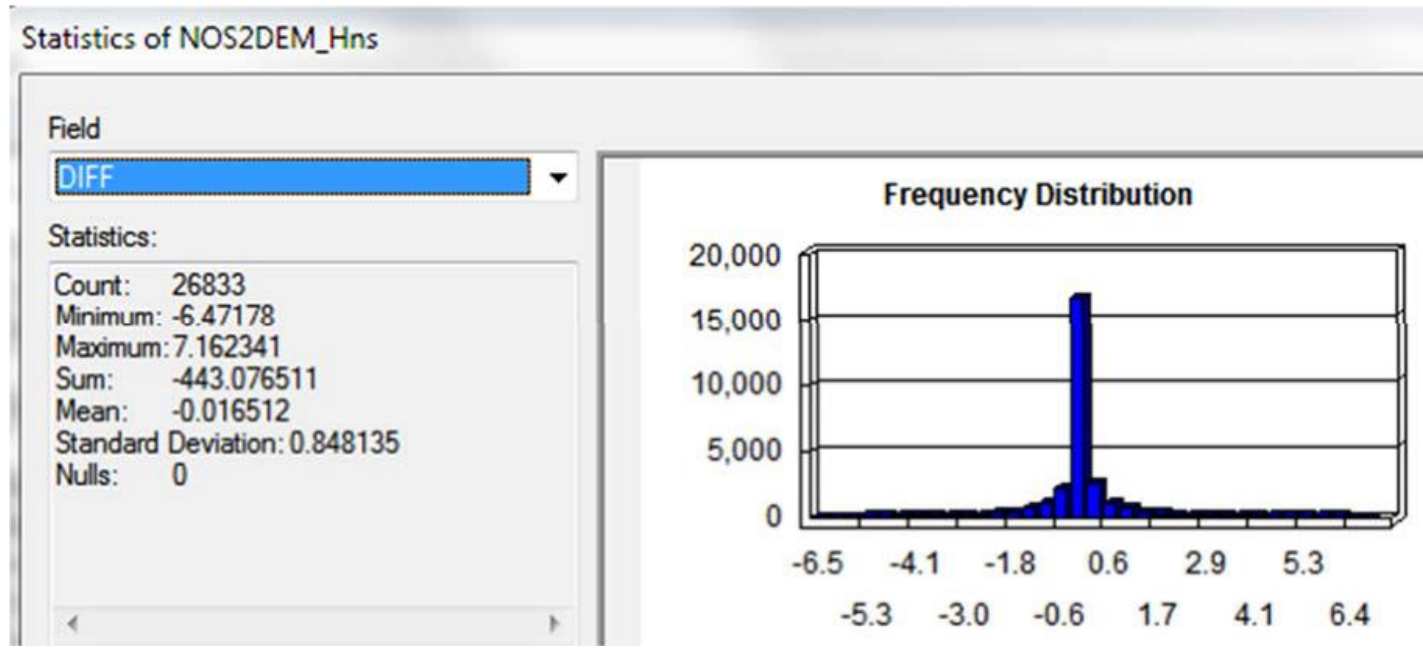

Figure 17. Comparison of NOS survey points to new Haines 8/15-arc-second DEM; mean offset is $-0.016 \mathrm{~m}$ with a maximum offset of $7.16 \mathrm{~m}$.

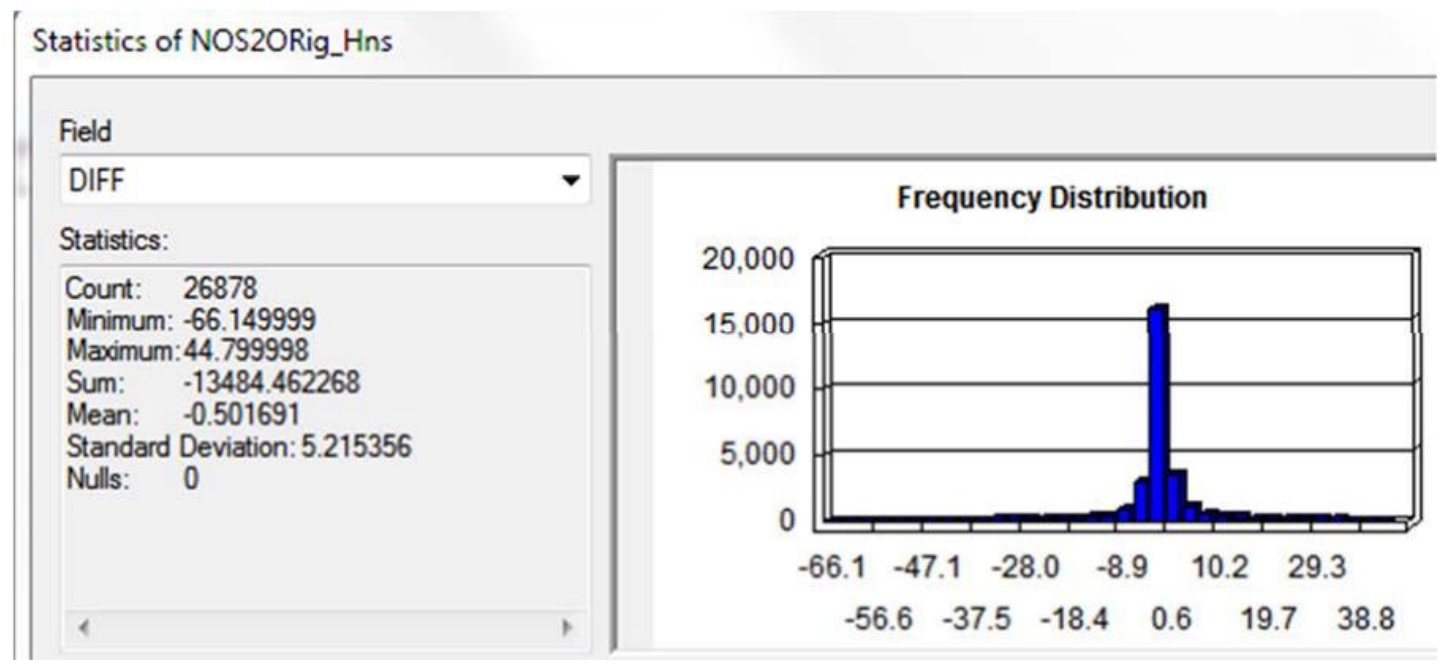

Figure 18. Comparison of NOS survey points to 8/3-arc-second Southeast AKDEM; mean offset is $-0.5 \mathrm{~m}$ with a maximum offset of $-66.15 \mathrm{~m}$. 
Table 5. Summary of the comparisons between source data and DEMs, both new 8/15-arcsecond DEMs and existing 8/3-arc-second DEM.

\begin{tabular}{|c|c|c|c|}
\hline & Skagway 8/15 DEM & Haines 8/15 DEM & 8/3 DEM \\
\hline \multicolumn{4}{|l|}{ SKAGWAY GPS } \\
\hline mean offset & $0.097 \mathrm{~m}$ & & $-4.723 m$ \\
\hline max offset & $3.481 \mathrm{~m}$ & & $-50.355 m$ \\
\hline \multicolumn{4}{|l|}{ HAINES GPS } \\
\hline mean offset & & $-0.069 m$ & $-5.963 m$ \\
\hline max offset & & $11.84 \mathrm{~m}$ & $-44.447 m$ \\
\hline \multicolumn{4}{|l|}{ NOS Survey } \\
\hline mean offset & $-0.046 m$ & $-0.016 m$ & $-0.501 m$ \\
\hline max offset & $32.439 \mathrm{~m}$ & $7.162 \mathrm{~m}$ & $-66.149 m$ \\
\hline
\end{tabular}

\section{Conclusion}

We constructed two new 8/15-arc-second bathymetric-topographic DEMs to support numerical tsunamiwave inundation modeling and mapping in the communities of Skagway and Haines, Alaska. The spatial resolution of these grid cells satisfies NOAA minimum recommended requirements for computation of tsunami inundation (National Tsunami Hazard Mapping Program [NTHMP], 2010). Additional requirements are detailed by the NTHMP Mapping \& Modeling Subcommittee ${ }^{10}$. The new DEMs were also produced in accordance with NGDC best practices (Caldwell and others, 2011), using the highest-resolution and most current hydrographic surveys, and the best topographic datasets available to us at this time. We ensured that the horizontal geographic coordinates for all data points incorporated during the construction of this DEM are correctly referenced to the WGS84 horizontal datum and that all of the depth values are referenced to the MHHW vertical datum. This report summarizes these data sources and the methodologies used to integrate these data into the final DEMs.

\section{Acknowledgments}

The authors thank Kelly Carignan (Cooperative Institute for Research in Environmental Sciences, University of Colorado at Boulder) for sharing her time and knowledge; and George Plumley (State of Alaska, Division of Community and Regional Affairs, DCRA) for providing data used in developing the Skagway DEM.

This project was supported by the National Oceanic and Atmospheric Administration under Reimbursable Services Agreement ADN 0931000 with the State of Alaska's Division of Homeland Security and Emergency Management (a division of the Department of Military and Veterans Affairs).

Data acquisition for this publication is sponsored by the Cooperative Institute for Alaska Research with funds from NOAA under cooperative agreement NA080AR4320751 with the University of Alaska Fairbanks.

We thank Ken Macpherson (Alaska Earthquake Center) for his help with the RTK GPS survey in Haines and Skagway, and Nicole Kinsman (Alaska Division of Geological \& Geophysical Surveys) for her valuable comments and suggestions to improve the manuscript.

${ }^{10}$ http://nws.weather.gov/nthmp/mapping subcommittee.html 


\section{References}

Applied Imagery, 2013, Quick Terrain Modeler: Chevy Chase, MD, Applied Imagery. www.appliedimagery.com

Caldwell, R.J., Eakins, B.W., and Lim, E., 2011, Digital elevation models of Prince William Sound, AlaskaProcedures, data sources, and analysis: Boulder, CO, U.S. Department of Commerce, NOAA, National Geophysical Data Center, Marine Geology and Geophysics Division, Technical Memorandum NESDIS NGDC-40, http://www.ngdc.noaa.gov/dem/squareCellGrid/getReport/735.

Caldwell, R.J, Taylor, L.A., Eakins, B.W., Carignan, K.S., and Collins, S.V., 2012, Digital elevation models of Juneau and Southeast Alaska-Procedures, data sources and analysis: Boulder, CO, U.S. Department of Commerce, NOAA, National Geophysical Data Center, Marine Geology and Geophysics Division, Technical Memorandum NESDIS NGDC-53, 76 p, http://www.ngdc.noaa.gov/dem/squareCellGrid/getReport/437.

ESRI, 2011, ArcGIS Desktop, Release 10: Redlands, CA, Environmental Systems Research Institute. www.esri.com

Leica Geosystems AG, 2002, GPS User Manual, Version 4, Leica Geosystems AG, Heerbrugg, Switzerland, 62 p.

MathWorks, Inc., 2012, MATLAB and Statistics Toolbox, Release 2012: Natick, Massachusetts, MathWorks, Inc.

National Tsunami Hazard Mapping Program (NTHMP), 2010, Guidelines and best practices for tsunami inundation modeling for evacuation planning: National Oceanic and Atmospheric Administration (NOAA), NTHMP Mapping \& Modeling Subcommittee. http://nws.weather.gov/nthmp/modeling guidelines.html

Nicolsky, D.J., Suleimani, E.N., Freymueller, J.T., and Koehler, R.D., in review, Tsunami inundation maps of Fox Islands Communities, including Dutch Harbor and Akutan, Alaska: Alaska Division of Geological \& Geophysical Surveys Report of Investigation.

Nicolsky, D.J., Suleimani, E.N., Freymueller, J.T., and Koehler, R.D., in review, Tsunami inundation maps of the City of Sand Point, Alaska: Alaska Division of Geological \& Geophysical Surveys Report of Investigation. 